\title{
Potential of Homestay Tourism Based on Seaweed Cultivation from the Views of Seaweed Cultivators in District of Semporna Sabah, East Malaysia
}

\author{
Rosazman Hussin ${ }^{1}$, Suhaimi Md. Yasir ${ }^{2}$ and Velan Kunjuraman ${ }^{3}$ \\ ${ }^{1,3}$ The Ethnography and Development Research Unit, Faculty of Humanities, Arts and Heritage, \\ Universiti Malaysia Sabah, 88400 Kota Kinabalu, Sabah, Malaysia. \\ ${ }^{2}$ Seaweed Research Unit, Faculty of Science and Natural Resources, Universiti Malaysia Sabah, \\ 88400 Kota Kinabalu, Sabah, Malaysia.
}

\begin{abstract}
Community participation in tourism development especially among fisherman and farmers has begun to given serious attention by the government whereby the communities are given opportunities to engage in tourism development programmes in order to enhance their quality of life. In order to encourage local community participation in tourism development in rural areas, participants' perceptions regarding tourism activities are important aspect to be sought. Good or bad perceptions from the community towards tourism development are important because it can determine the success of the programme. Firstly, this paper aims to explore the views or perceptions of seaweed cultivators towards homestay tourism which is based on seaweed cultivation in the District of Semporna, Sabah. Qualitative and quantitative research approaches have been applied in this study, such as the usage of the face to face interviews survey using survey questionnaires and field observation as primary methods. The findings show that the majority of the respondents have a positive perception of homestay tourism based on seaweed cultivation, such as the acceptance of visits by the tourists to their working place. Seaweed cultivators agreed that this tourism activity bring additional income to them. Activities that can become tourist attractions include tying seaweed seeds on a casino table. Moreover, the tourists have an opportunity to take a boat to see the seaweed farm, and take pictures of seaweed activities and so on. These findings also revealed that the majority of the respondents assumed that the visits of the tourists would motivate them to carry out the activity with more enthusiasm. This shows that seaweed cultivation could become a new tourism product which has great potential to develop in the district of Semporna, Sabah.
\end{abstract}

\section{Introduction}

Tourism sector is considered as an important asset in a country [1] and developing countries began to give serious attention to the tourism industry in their respective countries. Developing countries basically utilize tourism as an important mechanism to increase domestic and foreign investment [23], development of infrastructure [4] as well as employment opportunities [5-6], through the exchange 
of currencies [6-7]. Malaysia is no exception in this regard. Tourism sector in Malaysia can be categorised as at a decent level. This can be proved by the number of tourist arrivals in the country which have increased by 25.03 million, registering a total expenditure of MY60.6 billion (USD 46.26 billion) in 2012 differing from the previous year which only recorded a turnover of 24.71 million tourist arrivals and total expenditure of 58.3 billion [8]. Therefore, tourism has the same potential compare to other sectors such as the manufacturing and agricultural sectors.

\section{Tourism in Sabah}

The government is highly concerned about the development of the tourism industry in every state of Malaysia and ensures that the development in all of the states are at par with one another. Sabah is rich in natural resources which have the potential to fuel the country's economy. Natural resources such as forests, peaks and islands became important elements in eco-tourism. Moreover, the unique culture in Sabah's community attracts tourists to Sabah [9]. In terms of economy, the tourism industry in the state has a significant impact on the revenue. The number of tourists who visited the state, either domestic or international tourists is constantly increasing. This is supported by the statistical data issued by the Minister of Tourism, Culture and Environment. Datuk Seri Panglima Masidi says that Sabah tourism is income in 2013 was recorded at RM6.35 million, becoming the main source of income in the state. In addition, domestic tourism has contributed 68 percent or 2.29 million to the country's income, an increase of 18.6 percent of the total domestic tourism in 2012 [10].

Sabah has many popular tourist destinations such as Tunku Abdul Rahman Park, Kinabalu National Park, Poring Hot Springs, and the Sepilok Orang Utan Rehabilitation Centre. In 2000, the Kinabalu National Park has been listed in the World Heritage Sites, and that indicates the state has vast potential in strengthening Malaysia's position as an attractive tourist destination. In addition to the above listed tourist destinations, Sabah is also well known with its cultural tourism such as NunukRagang and homestay tourism [11]. There are several tourist homestays run by the local community in the state such as Atamis Homestay in Kundasang [1], Village Homestay in Kiulu Pukak [12], Miso Walai Homestay in Batu Puteh, Kinabatangan [13], and Walai Tokou Homestay in Kundasang [14]. Homestay programme has also has the ability to generate income for the Malaysian economy. For example, a total of 133,689 people had visited the homestay from January to May 2012. This include 110,322 domestic tourists and 23,367 foreign tourists, an increase of $70.7 \%$ over last year which was only 78,333 people. The total income from the homestay programme for the first five months of 2012 was RM 7,376,446.50 $(+53.1 \%)$. This total is higher than the total in the months of January to May of 2011 which was only MY4, 817,158.30.30 [15]. So, certainly homestay programme in Malaysia has the potential to grow and stay competitive.

\section{Homestay Tourism Based on Seaweed Cultivation Activities in Semporna: An Introduction}

Semporna is one of the areas that are close to Tawau. In Semporna, there are several tourist attractions such as islands of Mabul and Sipadan. Semporna became the centre for marine tourism activities and is still under development. Marine tourism is usually known for its beautiful beaches and coral reefs. Boat Transport is one of the special transports where travellers have to take the boat to go to islands near Semporna. Moreover, tourism in Semporna became popular when there are constructions of new hotels and restaurants in the area. These help Semporna to be known as a tourist destination, thus leisure travellers will be keen to visit Semporna. Semporna is a busy district which receives tourists every day. One of the key factors that attracks tourists to visit Semporna is the unmatched sea water clarity. Therefore, the many water activities are carried out such as diving, snorkelling, swimming and fishing. The tourists may enjoy the beauty of nature with a visit to nearby islands such as Sipadan Island, Mabul Island, Kapalai Island, Mataking Island and Sibuan Island. A marine specialty in Semporna District has prompted the government to introduce measures which strategies can help to develop the tourism industry in the area. According to Prabahkaran, et al. [16], Semporna District has 
a diverse marine motivate the visitors to visit remote destinations in the state. Elements like these are sure to develop a tourism industry based on natural resources such as seaweed cultivation. Stakeholders as Semporna District Office has identified 10 reasons tourists visited Semporna [17]: (1) Scuba diving, (2) Island shopping, (3) Picnic area, (4) Water villa, (5) Archaeological sites, (6) Fishing, (7) Water festival (Regatta Lepa), (8) honeymoon, and (9) Seafood Heaven.

Apart from the above, Semporna is also popular with seaweed cultivation by fishermen communities along the coast. Semporna is one of the locations where it undertakes seaweed activities on a large scale in Malaysia. In Southeast Asia such as the Philippines, Indonesia and Sulawesi seaweed species that is commonly cultivated are Kappaphycus and Eucheuma and exported abroad [18]. There are many different species of seaweed was cultivated by coastal communities in Malaysia. In Peninsular Malaysia, the species of seaweed such as Caulerpa,Sargassum, Ulva, and EnteromorphaAcanrophora are typically undertaken by communities in coastal especially fishermen community [19]. In Sabah, seagrass species such as Eucheumaspinosum and Kappaphycusalvarezili is the only type of seagrass cultured by fishermen community [20]. Seaweed cultivation activity has a great potential to serve as a unique tourism product in Semporna since it is cultivated on a large scale by fishermen communities as their main or side income. Seaweed cultivation activities in Sabah are concentrated in Semporna, Lahad Datu, Kudat and Kunak covering 7,535 hectares of the sea area. Semporna has been a tremendous interest because the fishermen community in most of the islands in the location carry out seaweed cultivation activities although seaweed is relatively new in the tourism industry, in collaboration with stakeholders and fishermen community, this activity can be used as a tourism product in the future, contributing to the country's economic income and improve the socioeconomic level of the communities that are working on the seaweed cultivation.

The homestay programme is identified as a mechanism to promote seaweed cultivation tourism which can be used as one of the tourism products to attract tourists. The packages offered through the homestay programme are one way to promote seaweed cultivation as a unique tourism product. The seaweed cultivation activities attract the interest of tourists to witness the activities that are run in the seaweed industry. There are several islands near Semporna where seaweed cultivation activities are actively conducted and this may attract tourists to pay for a visit namely to Omadal Island, Selakan Island and Sebangkat Island. It is very important to ensure that the seaweeds participate in the process of developing as a tourism product. Without the participation of the local communities, the tourism projects will definitely not succeed. Err [21] argues that without the participation of local communities, sustainable tourism in Malacca would not be realised. The concept of participation by Scheyvens is closely-related to the neopopulist and sustainable development approach. Neopopulist approach focuses on people in the context of small-scale, local, and bottom-up approaches to achieve development. However, sustainable development approach emphasizes the environment as the main priority in achieving development [22].

For Tosun [23], community participation in development is a voluntary act of an individual to take a chance and social responsibility. This process requires the cooperation of the community in all aspects of development planning so that the projects are implemented properly. In the process of tourism development, community participation can be viewed from two perspectives, namely the decision-making process and the resulting benefits of such a development [24].

\section{Studies on the Views or Perceptions of the Local Communities on the Development of Tourism}

Tourism involving local communities often needs the support of the communities that occupied the destination. Without their support, the tourism activities might not achieve the goal of the development. This is often related to the extent of the impact that tourism can fulfil the needs of the communities with their perception to move forward in life. Studies related to the perceptions of communities on tourism are done by foreign scholars in their geographic areas in the country [25-29]. However, there are some studies done by local scholars [30-33]. 
Studies done by Perdue et al. [27] and Akis et al. [28], confirm that local communities gain benefits in terms of the economic aspect and enable them to support the tourism development in their area. Studies by Wall [29] in Bali, Indonesia found that the local community has a positive outlook when they receive benefits from tourism development. Aside from the economic benefits, sociocultural and environmental aspects of the trade-off are also important factors for the development of the community tourism [27]. For example, from the socio-cultural perspective, tourism can develop or increase the demand for cultural products such as handicrafts which maintain traditional ideas and culture [34].In studies by Oviedo-Garcia et al. [35] on tourism in Santipoce found that people have a positive view on the high level of tourism that benefits them. This gives them the confidents to support the development of the tourism in their area. A review by Marzuki [30] in Langkawi found that people in the area receive the benefits and negative impacts of tourism development. The study found that residents receive more benefits than negative effects in the socio-economic aspect of the area such as offering opportunities for employment, business and infrastructure facilities. The study also shows that the development of tourism in Langkawi benefits the population in terms of the opportunity to be engaged in entrepreneurial activities. However, the study also showed the negative effects of the social and environmental aspects. Residents in the area found that there was a monopoly by traders from the mainland for accommodation, goods and transport businesses.

\section{Community-Based Tourism Planning Approach}

Community-based tourism planning approach is an approach that emphasizes community participation in tourism development [36]. In other words, community-based tourism planning approach also has the same meaning with a "bottom-up" approach which emphasizes community participation. Community participation in tourism development and planning has received a profound attention from many tourism researches [37-40]. This approach emphasizes community participation in tourism development and that benefit from tourism to be distributed to all [41].

According to this approach, there should be appropriate measures when planning a tourism development involving the community so that the community agrees with the planning that is going to be carried out in their area. Therefore, in this study the researchers highlight the potential of seaweed cultivation as a new tourism product in Semporna, Sabah and identify views of the seaweed cultivators in the area. There are two objectives in this study. They are as follows:

i. To identify demographic backgrounds of seaweed cultivators interested in becoming homestay operators;

ii. To identify views of the seaweed cultivators on seaweed cultivation activities homestay based tourism; and to identify the monitoring method on the expected number of tourist arrivals in the seaweed cultivation site.

\section{Methodology}

The study was conducted on three islands located in Semporna namely Selakan Island, Omadal Island, and Sebangkat Island. Initial field survey was conducted on the three islands in Semporna to identify seaweed cultivation activities conducted by seaweed cultivators in September 2012. The Islands were chosen because the majority of the fishing communities are involved in seaweed cultivation as their full or part time job. In addition, these islands also have the potential to become tourist destinations because of the seaweed cultivation which is a unique way to serve as a tourism product that can attract the tourists. This study uses a quantitative approach to get the data which is by using face to face interview survey [42]. A total of 80 local communities were selected based on non-probability purposive sampling as respondents from the three islands located in Semporna District. Nonprobability purposive sampling in this study is considered as suitable for a group of subjects that have certain characteristics selected as the respondents. In this study, the respondents were selected based on the purpose of the study in which respondents must have experience in the kelp industry on seaweed cultivation activities as a full or part time job. Aside from face to face interview survey 
method, the researchers also performed field observations in order to get the data. A questionnaire of 12 close-ended questions was used by the researchers to survey the respondents. The close-ended questions are intended facilitate the respondents answering the questions, as well as to save the respondents' and researchers' time [43]. In addition, measurements on a Likert scale responses were used. According to Likert Resis [84], data that is collected through a Likert scale have higher reliability compared to other scales. There are some scale of measurement used in a study which are 1$3,1-5,1-7$ or $1-9$. This study used eight options, $1=$ highly disagree, $2=$ disagree, $3=$ not sure, $4=$ agree, $5=$ strongly agree, $6=$ no response, $7=$ not relevant, $8=$ do not know to measure items that have been built. The data were analysed using Microsoft Excel 2007 and involves a descriptive analysis.

\section{Data Analysis and Research Findings}

Table 1. Demographical Analysis of the Respondents

\begin{tabular}{|c|c|}
\hline Information & $\mathrm{N}=\mathbf{8 0}$ \\
\hline \multicolumn{2}{|l|}{ Gender (\%) } \\
\hline Male & 65.0 \\
\hline Female & 35.0 \\
\hline \multicolumn{2}{|l|}{ Education (\%) } \\
\hline No School & 33.8 \\
\hline Primary School & 35.0 \\
\hline Secondary School & 18.8 \\
\hline Diploma & 2.5 \\
\hline Bachelor's & 1.2 \\
\hline Others & 7.5 \\
\hline No answers & 1.2 \\
\hline \multicolumn{2}{|c|}{ Residential location (\%) } \\
\hline Selakan Island & 37.5 \\
\hline Sebangkat Island & 47.5 \\
\hline Omadal Island & 15.0 \\
\hline \multicolumn{2}{|l|}{ Age $(\%)$} \\
\hline $17-27$ years & 38.8 \\
\hline $28-38$ years & 30.0 \\
\hline $39-49$ years & 13.8 \\
\hline $50-60$ years & 8.8 \\
\hline $61-71$ years & 1.2 \\
\hline No answers & 7.5 \\
\hline \multicolumn{2}{|l|}{ Income $(\%)$} \\
\hline$<500$ & 58.8 \\
\hline $501-1000$ & 16.2 \\
\hline $1001-2000$ & 1.2 \\
\hline $2001-3000$ & 1.2 \\
\hline Not determine & 5.0 \\
\hline Not sure & 2.5 \\
\hline Not relevant & 8.8 \\
\hline No answers & 6.2 \\
\hline \multicolumn{2}{|c|}{ Maritial Status (\%) } \\
\hline Unmarried & 32.5 \\
\hline Married & 65.0 \\
\hline Widowed/divorced & 2.5 \\
\hline
\end{tabular}

Source: Research Analysis, 2014 
Based on Table 2, the results of this study shows that as many as 80 seaweed cultivators were interviewed in the three research area namely Selakan Island, Sebangkat Island and Omadal Island. There are 52 respondents $(65.0 \%)$ consisting of men and 28 respondents $(35.0 \%)$ consisting of women. The survey shows that there are more male than female respondents at 30 percent. The findings showed 35.0 percent of the respondent had their primary school education while 33.0 percent of the respondents never attended school. Since the majority of the respondents had low level of education, this made them less likely to have the knowledge and skills in tourism planning process in the region. In addition, they are also lack of understanding on the process of tourism development that will be carried out by the authorities in the area. The majority of the respondents have jobs as a seaweed cultivator earning less than RM 500, that is by the percentage of 58.8 percent. Next, a total of 13 respondents receive a monthly income of between RM501 to RM1000. Therefore, it can be concluded that the majority of the respondents are earning less than RM500. This makes it hard for them to improve their living standard. The study also found that 38.8 percent of the respondents are between the ages of 17 to 27 . Secondly, 24 of the respondents are from the ages of 28 to 38 which is a total percentage of 30.0 percent. In addition, this study also found that $52(65.0 \%)$ of the seaweed cultivators are married. A total of 32.5 percent of the respondents in this study are not married and 2.5 percent are widows/widowers. Overall, most of the seaweed cultivators are married and are considered as having appropriate jobs. Thus, they are the right participator for the homestay tourism programme.

\subsection{Seaweed Cultivators' Outlooks on Tourism Activities and the Monitoring Method on the Tourist Arrivals}

This section is divided into two themes, namely (1) Seaweed cultivators' outlook on offerings for tourism activity related to seaweed cultivation, and (2) Monitoring method on the expected tourist arrivals.

Table 3. Seaweed Cultivators Outlooks on Tourism Activities Based on Seaweed Cultivation

\begin{tabular}{|c|c|c|c|c|c|c|c|c|c|}
\hline \multirow{2}{*}{\multicolumn{2}{|c|}{ Variables Examined }} & \multicolumn{8}{|c|}{ Scale (\%) } \\
\hline & & 1 & 2 & 3 & 4 & 5 & 6 & 7 & 8 \\
\hline \multicolumn{10}{|c|}{ Theme 1:Seaweed Cultivators' outlooks on tourism activities based on seaweed cultivation } \\
\hline 1. & $\begin{array}{l}\text { I feel a sense of pride upon } \\
\text { visitors coming to see our } \\
\text { work }\end{array}$ & 3.8 & 3.8 & 7.5 & 58.8 & 20.0 & 3.8 & 1.2 & 1.2 \\
\hline 2. & $\begin{array}{l}\text { Tourist arrivals would bring } \\
\text { additional income to us. }\end{array}$ & 11.2 & 16.2 & 21.2 & 37.5 & 7.5 & 3.8 & 1.2 & 1.2 \\
\hline 3. & $\begin{array}{l}\text { Activities of tying seaweed } \\
\text { seeds is interesting to see by } \\
\text { the tourists. }\end{array}$ & 1.2 & - & 12.5 & 56.2 & 25.0 & 3.8 & 1.2 & - \\
\hline & $\begin{array}{l}\text { Tourists are to be allowed for } \\
\text { a practical experiences in } \\
\text { tying seaweed seeds, thus } \\
\text { giving valuable experience. }\end{array}$ & 1.2 & 2.5 & 15.0 & 52.5 & 22.5 & 3.8 & 1.2 & 1.2 \\
\hline
\end{tabular}

Source: Data Analysis, 2014

Note: $1=$ highly disagree, $2=$ disagree, $3=$ not sure, $4=$ agree, $5=$ strongly agree, $6=$ no response, $7=$ not relevant, $8=$ do not know 
4ICTR

Table 4. Monitoring Method of the Tourist Arrivals

\begin{tabular}{|c|c|c|c|c|c|c|c|c|c|}
\hline \multirow{2}{*}{\multicolumn{2}{|c|}{ Variables Examined }} & \multicolumn{8}{|c|}{ Scale $(\%)$} \\
\hline & & 1 & 2 & 3 & 4 & 5 & 6 & 7 & 8 \\
\hline \multicolumn{10}{|c|}{ Theme 2: Monitoring method of the tourist arrivals } \\
\hline 5. & $\begin{array}{l}\text { Tourists must obtain } \\
\text { permission from the kelp } \\
\text { industry before visiting the } \\
\text { seaweed cultivation sites }\end{array}$ & 5.0 & 3.8 & 22.5 & 42.5 & 17.5 & 6.2 & 1.2 & 1.2 \\
\hline 6. & $\begin{array}{l}\text { Only three groups of tourists } \\
\text { should be allowed to visit the } \\
\text { site in one day for every } \\
\text { company }\end{array}$ & 7.5 & 11.2 & 38.8 & 33.8 & 2.5 & 3.8 & 1.2 & 1.2 \\
\hline 7. & $\begin{array}{l}\text { Tourists are not allowed to } \\
\text { granting some money to the } \\
\text { cultivators }\end{array}$ & 10.0 & 6.2 & 41.2 & 27.5 & 8.8 & 3.8 & 1.2 & 1.2 \\
\hline 8. & $\begin{array}{l}\text { A group of tourists visiting } \\
\text { session should be between } 30 \\
\text { to } 45 \text { minutes }\end{array}$ & 5.0 & 13.8 & 33.8 & 35.0 & 6.2 & 3.8 & 1.2 & 1.2 \\
\hline 9. & $\begin{array}{l}\text { Tourists are allowed to take } \\
\text { pictures of seaweed } \\
\text { cultivation }\end{array}$ & 1.2 & - & 8.8 & 62.5 & 21.2 & 3.8 & 1.2 & 1.2 \\
\hline 10. & $\begin{array}{l}\text { Tourists are encouraged to } \\
\text { visit the seaweed cultivation } \\
\text { sites around } 10 \text { am until } 4 \mathrm{pm} \\
\text { only }\end{array}$ & 1.2 & 16.2 & 28.8 & 42.5 & 5.0 & 3.8 & 1.2 & 1.2 \\
\hline & $\begin{array}{l}\text { Tourist arrivals must be in a } \\
\text { small group }\end{array}$ & 10.0 & 8.8 & 21.2 & 45.0 & 7.5 & 5.0 & 1.2 & 1.2 \\
\hline & $\begin{array}{l}\text { Presence of tourists can } \\
\text { disrupt our work processes }\end{array}$ & 16.2 & 26.2 & 18.8 & 28.8 & 3.8 & 3.8 & 1.2 & 1.2 \\
\hline
\end{tabular}

Source: Data Analysis, 2014

Note: $1=$ highly disagree, $2=$ disagree, $3=$ not sure, $4=$ agree, $5=$ strongly agree, $6=$ no response, $7=$ not relevant, $8=$ do not $k$ now

Table 3 displays cultivators' outlook on offerings for tourism activities related to seaweed cultivation. The study found that the majority of the respondents which is 47 respondents $(58.8 \%)$ agreed with this statement. About 20 percent of the respondents strongly agreed that they have higher motivation when tourists came for a visit to see them doing their job at their working site and these findings suggest that the respondents welcomed tourists to pay for a visit to their seaweed cultivation site. The results show that the majority of the respondents, which is 30 respondents $(37.5 \%)$ agreed that the arrivals of tourists could bring them additional income. In addition, a total of 17 respondents (21.2) are not bound by it and doubt it. However, the majority of the respondents has a positive perception of tourist arrivals to their place and feels what it is a good chance for them to improve their socio-economic development through tourism. In addition, it was found that a total of 45 respondents $(56.2 \%)$ agreed with the statement that seaweed seedlings binding activity is a very interesting activity for tourists viewing. There were 20 respondents that strongly agreed with this statement. Findings of this study support the objectives that seaweed cultivation can be used as a tourism product in the area and the respondents have a positive opinion in this regard. In addition, it was found that the majority of the respondents in the survey which is by 42 respondents $(52.5 \%)$ agree with the view that tourists are allowed to try to tie the seaweed seed in the casino tables. A total of 18 respondents strongly agreed with this view and this is considered as they want to promote seaweed cultivation as a tourism product in the area. 
Based on Table 4, a total of 34 respondents (42.5\%) agreed that tourists must obtain permission from the kelp industry before visiting the seaweed cultivation site. However, 33.8 percent of the respondents agreed that only three groups of tourists should be allowed to visit the site in one day for every company. Table 4 also describes the information related to the issue of granting some cash to the seaweed cultivators. Findings showed that a total of 33 respondents $(41.2 \%)$ were not identified in the issue of granting the seaweed cultivators in the form of cash. They have doubts in this regard and it is beyond the knowledge of the respondents. In addition, the study found that a total of 22 respondents agreed with this. If tourists are allowed to grant cash to the cultivators, it is likely that it can increase revenues and motivate them to continue to be seaweed cultivation activists. Seaweed cultivators also agreed (35\%) that a group of tourists visiting session should be between 30 to 45 minutes. As shown in Table 4, it was found that a total of 31 respondents $(38.8 \%)$ were not sure on the procedures of seaweed cultivation tourists visits. In this case, it can be categorized that these respondents have little knowledge on the procedures of tourist visits in their area and there are still some respondents who have no knowledge on this case.

Thus, the findings of this study found that almost all of the respondents which is by 50 people $(62.5 \%)$ agreed that tourists are allowed to take pictures of seaweed cultivation. It is also important for cultivators to feel that seaweed cultivation is something unique and should be known by the tourists. A total of 17 respondents (21.2\%) also strongly agree in this respect and encourage tourists to take pictures. From the aspect of time duration for the sightseeing session at the cultivation site, the results show that a total of 34 respondents $(42.5 \%)$ agreed in this case. This is because it is the appropriate time for photo taking on seaweed cultivation activity. During the sightseeing session, the travellers will have the opportunity to see the seaweed cultivation process from the early stages until the end. With this, they get to know and understand the real seaweed cultivation process. Additionally, there were also some respondents which is by 28.8 percent who were not sure in this case. The study also found that 36 respondents $(45.0 \%)$ agreed with this view. This is considered as important because the cultivators are not interested when their jobs are affected by the arrivals of large numbers of tourists. In addition, the space factor is also taken into account where the space provided only have the ability to cultivate seaweed and it is difficult to place a large number of tourists. Finally, a total of 23 respondents $(28.8 \%)$ agreed with the details at a lot of seaweed cultivation at any given time. Therefore, they do not agree with the presence of tourists which can disrupt their work processes. This is because they have targets to complete tasks in the area. However, a total of 21 respondents responded that it will enhance their motivation level indirectly when tourists come and see their hard work.

\section{Conclusion and Discussion}

Overall, this study was able to achieve all three objectives. The first objective of which is to identify the demographic backgrounds of the seaweed cultivators. In this study a total of 80 respondents participated which consisted of 52 men and 28 women. The majority of men tend to carry out seaweed cultivation activity compared to women in the three islands namely Selakan Island, Sebangkat Island and Omadal Island. The study found that most of the respondents had primary school education by 35.0 percent, followed by respondents who have never attended school amounting to 33.0 percent. The majority of respondents working as seaweed cultivators are earning less than RM500 at the percentage of 58.8 percent. Thus, it can be concluded that the majority of respondents earn less than RM500 a month and this causes them to not be able to improve the socio-economic development.

Through the findings of this study, it can be concluded that the majority of the respondents had a positive view towards making seaweed cultivation as a tourism product in their area. The study also found that the cultivators agreed that tourism activities based on seaweed cultivation can improve their socio-economic status. This situation is supported by previous studies by [27-28, 30, 35]. Review by Oviedo-Garcia et al. [35] found that the local population of Santipoce giving their views positively rather than negatively in which they receive benefits from tourism activities in their area while supporting the development project. Western scholar also stressed that local population positive 
outlook on the development of tourism is an important point and may have a positive impact on the planning of tourism development [35, 45-47]. Murphy [38] has emphasized that community input and participation in tourism planning should be taken into account so that the mission of the tourism project can be achieved.

The results of this study concluded that the majority of the respondents had positive views on the offerings of seaweed cultivation as a tourism product in their area. This is a good thing where they realise that this offerings will not only provide additional income but would also increase their potential to become entrepreneurs in the field of tourism when they set up a homestay programme in their area as well as making seaweed cultivation as a unique tourism product. Development of rural areas, particularly Semporna can be developed if the coastal communities are also engaged in business activities. Besides, business activities help to improve their standard of living in terms of their socioeconomic. In addition, the tourism industry in the state began identifying seaweed cultivation as a tourism product in Semporna and other locations where seaweed cultivation is performed on a large scale. This could indirectly increase the state income itself and help to increase the country's Gross Domestic Product (GDP). This study is proposed to all the stakeholders, particularly the tourism industry in the state of Sabah. The Ministry of Tourism, Culture and Environment Minister should introduce measures that would encourage rural communities to participate in the tourism business particularly in the homestay programme. They can provide some incentives or capital for the coastal communities to participate in the homestay business. This is because it appears that the majority of fishermen community in Semporna receives less than RM500 and financial constraints pose an obstacle for them to set up a homestay programme in their area. Therefore, the responsible parties should take concrete steps so that the fishermen community can change or improve their lives by engaging in business activities such as the establishment of a homestay programme. Through this study it was found that seaweed cultivation has the potential to become a tourism product. Thus, it is job of the responsible parties such as Semporna District Fisheries Department in Sabah to promote the communities in the area. If this happens, offerings on seaweed cultivation as the first tourist product in the country will become a reality. The study is only a preliminary and comprehensive study for the needs of the future. Future studies should focus on the reaction or other points of view such as tour operators, government officials, NGOs and village chiefs in promoting seaweed cultivation as a tourism product.

\section{References}

1. V. Kunjuraman, R. Hussin, Satisfaction of Domestic Tourist with the Homestay Programme in Mesilou Village, Kundasang, Sabah. Proceedings of the 3rd Regional Conference on Tourism Research, 29-31 Oct, 2013, Langkawi, Malaysia. 18-27 (2013)

2. J. S. Akama. The role of government in the development of tourism in Kenya. Int. J. Tou. Resea 4, $1-13(2002)$

3. C. L. Jenkins. The use of investment incentives for tourism projects in developing countries. Tou Manage 3, (June), 91 (1982)

4. T. Nimmonratana. Impacts of tourism on a local community: A case study of Chiang Mai. In K. S. Chan. (Ed). Tourism in Southeast Asia: A new direction, 6. New York: Haworth Press. (2000).

5. E. de Kadt. Social planning for tourism in the developing countries. Annals Tou Resea 6, 1, 36-48 (1979)

6. M. A. H. Bhuiyan, C. Siwar, S. M. Ismail. Tourism development in Malaysia from the perspective of development plans. Asi Soc Sci 9, 9, 11-18. (2013)

7. A. Nankervis. Dreams and Realities: Vulnerability and the tourism industry in Southeast Asia: A framework for analyzing and adapting tourism management toward 2000. In K. S. Chan. (Ed). Tourism in Southeast Asia: A new direction, 49-61. New York: Haworth Press. (2000)

8. Tourism Malaysia. www.MOTAC.gov.my accesed on 2 May 2013

9. S. Ghazali, M. Sirat. Global Ecotourism and local communities in rural areas. Pulau Pinang: Universiti Sains Malaysia Press. (2011) 
10. Tourism Minister's speech. www.theborneopost.com accsed on 3 March 2014.

11. T. M. Tangit, A. Adanan, S. A. Kibat. Tourism development and its impact on residents' quality of life: A case study on Malaysia's First World Heritage Site, Kinabalu Park, Ranau, Sabah. Proceedings of the 3rd Regional Conference on Tourism Research, 29-31 Oct, 2013, Langkawi, Malaysia, 275-283 (2013)

12. P. L. Yong. Projek Miso Walai Homestay dan Penyertaan Komuniti Tempatan: Satu Tinjauan di Mukim Batu Putih, Hilir Kinabatangan, Sabah. Unpublished Academic Practice. School of Social Sciences, Kota Kinabalu: Universiti Malaysia Sabah. (2004)

13. R. Hussin. Ecotourism and Community Participation in the Homestay Programme of Sukau Village: $\quad$ Long-term or Limited Benefits? Jur Sarj 23, 72-86 (2008)

14. A. Adrianna, J. Cindy, O. Nor'ain. Study of tourists' expectation and perception towards products and services offered by Walai Tokou Homestay Kundasang Sabah. In N. Othman \& M. Jamaludin (Eds.). The 3rd Tourism outlook conference \& global events Congress II, Heritage \& Tourism: Alliance \& Network relationship, Event management \& Event Tourism, Shah Alam: UITM (UPENA). (2007)

15. Ministry of Tourism Malaysia (MOTOUR) (2012a), ETP: Transforming tourism to the new heights.

16. S. Prabhakaran, V. Nair, S. Ramachandran. Marine waste management indicators in a tourism environment. Worldwide Hospitality and Tourism Themes, Emerald Group publishing. 5, 4, 365$376(2013)$

17. District Office Semporna. Tourism: 10 reasons to visit Semporna, District Office Semporna, Sabah. (2014)

18. L. Sievanan, B. Crawford, R. Pollnac, C. Lowe. Weeding through assumptions of livelihood approaches in ICM: Seaweed farming in the Philippines and Indonesia. Oce \& Coas Manage 48, 297-313 (2005)

19. S.M. Phang. Seaweeds of Cape Rachado Port Dickson. Nature Malaysiana, 10, 9-15 (1989)

20. C. R. Kaur, \& M. Ang. Seaweed culture and utilization in Malaysia: Status, challenges and economic potential. Paper was presented at MIMA Seminar on Developing the seaweed aquaculture sector, 27 October 2009, Kuala Lumpur: MIMA. (2009)

21. A. C. Err. Pembangunan pelancongan lestari di Melaka: Perspektif pelancong. Mal Jour of Soc and Spa 9, 3,12-23Available at www.geografia online. (2013)

22. R. Scheyvens. Tourism for Development: Empowering Communities. Harlow: Prentice Hall. (2002)

23. C. Tosun. Limits to Community Participation in the Tourism Development Process in Developing Countries. Tour Manage 21, 6, 613-633 (2000)

24. D. J. Timothy. Tourism and Community Development Issues. In R. Sharpley \& D. J. Telfer (Eds.), Tourism and Development: Concepts and Issues. England: Channel View Publications. (2002)

25. K. Andereck, K. Valentine, R. Knopf, C. Vogt. Residents' perceptions of community tourism impacts. Annals of Tou Res 32, 4, 1056-1076 (2005)

26. C. Jurowski, M. Uysal, R. Williams. A theoritical analysis of host community resident reactions to tourism. Jour of Tra Res 36, 2, 3-11 (1997)

27. R. Perdue, P. Long, L. Allen. Resident support for tourism development. Annals of Tourism Research, 17, 4 586-599 (1990)

28. S. Akis, N. Peristianis, J. Warner. Residents' attitudes to tourism development: The case of Cyprus. Tou Manage 17, 7, 481-494 (1996)

29. G. Wall. Perspective on tourism in selected Balinese Villages. Annals of Tou Res 23, 1, 123-138 (1996)

30. A. Marzuki. Resident attitudes towards impacts from tourism development in Langkawi Islands, Malaysia. World Applied Sciences Journal 12 (Special issue of Tourism and Hospitality) 2534(2011) 


\section{ICTR}

31. K. Kayat. Power, Social Exchanges and Tourism in Langkawi: Rethinking resident perceptions. Int. Jour. of Tou Res, 4, 171-191 (2002).

32. F. Aref, M. Redzuan. Community capasity building for tourism development. Jour of Hum Eco, 27, 21-25 (2009).

33. F. Aref, M. Redzuan, S. S Gill. Community Perceptions towards Economic and Environmental Impacts of Tourism on Local Communities. Asi Soc Sci, 5, 7, 130-137 (2009)

34. R. Kumar, S. S. Gill, P. Kunasekaran. Tourism as a poverty eradication tool for rural areas in Selangor, Malaysia. Glo Jour of Hum Soc Sci 12, 7, 21-26 (2012)

35. M. A. Oviedo-Garcia, M. Castellanos-Verdugo, D. Martin-Ruiz. Gaining residents' support for tourism and planning. Int. Jour. of Tou Res 10, 95-109 (2008)

36. E. Inskeep. Tourism Planning: An Integrated and Sustainable Development Approach. New York: Van Nostrand Reinhold. (1991)

37. W. Goudy. Evaluations of Local Attributes and Community Satisfaction in Small Towns. Rur Soci 42, 3, 371-382 (1977)

38. P. E. Murphy. Tourism: A Community Approach. London: Routledge. (1985)

39. T. B. Jamal, D. Getz. Collaboration Theory and Community Tourism Planning. Annals of Tou Res 22, 1, 186-204 (1995)

40. B. Bramwell. Participative planning and governance for sustainable tourism. Tou Rec Res 35, 3, 239-249 (2010).

41. R. Sharpley. Travel and Tourism. London: SAGE Publications Ltd. (2006)

42. R. K. Yin. Case Study Research: Design and Methods. ( $\left.3^{\text {rd }} \mathrm{ed}\right)$. Thousand Oaks: Sage Publications. (2003)

43. K. D. Bailey. Methods of social research. New York: Free Pr. (1984)

44. Y. P. Chua. Kaedah Penyelidikan. Kuala Lumpur: McGraw Hill Education (Malaysia). (2006)

45. D. Gursoy, C. Jurowski, \&, M. Uysal. Residents attitudes: A structural modelling approach. Annals of Tou Res 29, 79-105 (2002)

46. D. Ko, W. Stewart. A structural equation model of resident's attitudes for tourism development. Tou Manage 25, 521-530 (2002)

47. D. Gursoy, D. G. Rutherford. Host attitudes toward tourism: An improved structural model. Annals of Tou Res 31, 3, 495-516 (2004) 